\title{
Curcumin Enhances Docetaxel-Induced Apoptosis of 8505C Anaplastic Thyroid Carcinoma Cells
}

\author{
Jung Min Hong ${ }^{1, *}$, Chan Sung Park ${ }^{1, *}$, Il Seong Nam-Goong ${ }^{1}$, Yon Seon Kim², Jong Cheol Lee ${ }^{3}$, Myung Weol Han ${ }^{3}$, \\ Jung Il Choi ${ }^{4}$, Young Il Kim ${ }^{1}$, Eun Sook Kim ${ }^{1}$ \\ Departments of ${ }^{1}$ Internal Medicine, ${ }^{2}$ General Surgery, ${ }^{3}$ Otolaryngology, ${ }^{4}$ Biomedical Research Center, Ulsan University \\ Hospital, University of Ulsan College of Medicine, Ulsan, Korea
}

Background: Anaplastic thyroid cancer (ATC) is one of the most aggressive malignancies in humans, and its progression is poorly controlled by existing therapeutic methods. Curcumin has been shown to suppress inflammation and angiogenesis. In this study, we evaluated whether curcumin could augment docetaxel-induced apoptosis of ATC cells. We also analyzed changes in nuclear factor $\kappa \mathrm{B}(\mathrm{NF}-\mathrm{\kappa B})$ and cyclooxygenase-2 (COX-2) expression levels to delineate possible mechanisms of their combined action.

Methods: ATC cells were cultured and treated with curcumin and docetaxel alone or in combination. The effects on cell viability were determined by MTS assay. Apoptosis was assessed by annexin V staining and confirmed by flow cytometric analysis. Caspase, COX-2, NF-kB levels were assayed by Western blotting.

Results: Curcumin combined with docetaxel led to lower cell viability than treatment with docetaxel or curcumin alone. Annexin V staining followed by flow cytometric analysis demonstrated that curcumin treatment enhanced the docetaxel-induced apoptosis of ATC cells. Additionally, curcumin inhibited docetaxel-induced p65 activation and COX-2 expression.

Conclusion: We conclude that curcumin may enhance docetaxel's antitumor activity in ATC cells by interfering with NF-kB and COX-2. Our results suggest that curcumin may emerge as an attractive therapeutic candidate to enhance the antitumor activity of taxanes in ATC treatment.

Keywords: Thyroid cancer, anaplastic; Apoptosis; Curcumin; Cyclooxygenase 2; Docetaxel; NF-kappa B

\section{INTRODUCTION}

Anaplastic thyroid cancer (ATC) is one of the most aggressive malignancies in humans. Multidisciplinary treatments, including radiotherapy and chemotherapy, poorly control the progression of this disease, and the mean survival is less than 1 year after initial diagnosis [1]. Therefore, discovery of new

Received: 31 May 2013, Accepted: 11 October 2013

Corresponding author: Eun Sook Kim

Department of Internal Medicine, Ulsan University Hospital, University of Ulsan College of Medicine, 877 Bangeojinsunhwan-doro, Dong-gu,

Ulsan 682-714, Korea

Tel: +82-52-250-8837, Fax: +82-52-250-7048, E-mail: endo10@daum.net

*These authors contributed equally to this work. and improved therapeutic strategies are critical for improving the quality of life and survival rates of patients with ATC.

Curcumin is a polyphenolic natural product found in turmeric, a commonly used food coloring and flavoring agent. The active component of turmeric, curcumin, has been shown to have antiviral, antibacterial, antioxidant, anti-inflammatory, antiproliferative, and antiangiogenic activities [2,3]. Studies

\section{Copyright $(2014$ Korean Endocrine Society}

This is an Open Access article distributed under the terms of the Creative Commons Attribution Non-Commercial License (http://creativecommons.org/ licenses/by-nc/3.0/) which permits unrestricted non-commercial use, distribution, and reproduction in any medium, provided the original work is properly cited. 
conducted in both animals and humans have suggested that curcumin is a promising candidate for the treatment of inflammation and cancer [4-7].

Docetaxel is an anticancer microtubule-stabilizing agent that induces apoptosis by suppressing the microtubule dynamics of the mitotic apparatus [8,9]. Docetaxel arrests cells in the G2/M phase, leading to increased susceptibility of cancer cells to radiotherapies and chemotherapies [10-12]. It is severely doselimited because of its adverse side effects, including neutropenia, diarrhea, nausea, and fatigue [13]. Combination therapies to reduce its toxicity at higher doses and/or to increase its efficacy at lower doses are highly desirable, and could have a significant impact on therapeutic outcome. Studies have shown that docetaxel alone was only modestly effective against ATC in clinical trials [14]. However, available evidence suggests that combined therapy with radiation and/or other pharmacological agents may be more effective [15-17].

In this study, we attempted to increase the sensitivity of ATC cells to docetaxel by simultaneous treatment with curcumin and analyzed the apoptotic signaling pathways in treated cells. Here, we report for the first time that curcumin augments the growth-inhibitory and proapoptotic effects of docetaxel, possibly by interfering with nuclear factor $\kappa$ light-chain enhancer of activated $B$ cells (NF- $\kappa \mathrm{B})$ and cyclooxygenase-2 (COX-2) signaling pathways. Our results suggest that a curcumin-docetaxel combination could be a useful therapeutic agent for the treatment of ATC.

\section{METHODS}

\section{Materials}

Human anaplastic thyroid carcinoma cell lines $8505 \mathrm{C}$ and CAL62 were a gift from Dr. Shong (Asan Medical Center, University of Ulsan College of Medicine, Seoul, Korea). The ATC cell line FRO (wild type) was provided by J.A. Fagin (University of Cincinnati College of Medicine, Cincinnati, OH, USA), and the cell line KTC-2 was obtained from Kawasaki Medical School (Okayama, Japan) [18].

Docetaxel and curcumin were purchased from Sigma (St. Louis, MO, USA). They were dissolved in dimethyl sulfoxide (DMSO, Sigma) at appropriate concentrations prior to dilution in culture medium such that the final concentration of DMSO would not exceed $0.1 \%$.

Antiactin, antirabbit immunoglobulin G (IgG), and antimouse IgG horseradish peroxidase-conjugated secondary antibody were purchased from Santa Cruz Biotechnology (Santa
Cruz, CA, USA). Antibodies against NF- $\kappa$ B, cleaved caspase-3 and caspase-9 were obtained from Cell Signaling Technology (Beverly, MA, USA). A polyclonal antibody against COX-2 was procured from Abcam (Cambridge, MA, USA).

\section{Cell culture}

$8505 \mathrm{C}$, FRO, and KTC2 cells were grown in RPMI 1640 medium, and CAL62 cells were grown in Dulbecco's modified Eagle's medium and both media types were supplemented with $10 \%$ fetal bovine serum and $1 \%$ penicillin/streptomycin (all reagents from Invitrogen Life Technologies, Paisley, UK). Cells were grown in a $5 \% \mathrm{CO}_{2}$ humidified incubator maintained at $37^{\circ} \mathrm{C}$.

\section{Cell proliferation assay}

Cell viability was measured by a CellTiter 96 AQueous One Solution Cell Proliferation Assay according to the manufacturer's instructions (Promega, Madison, WI, USA). Aliquots of $4 \times 10^{3}$ cells were plated onto each well of a 96-well microplate (Falcon, Franklin Lakes, NJ, USA) in $100 \mu \mathrm{L}$ complete growth medium and incubated with $1,2,5,10$, or $20 \mathrm{nM}$ of docetaxel in the presence or absence of $1,5,10,25$, or $50 \mu \mathrm{M}$ curcumin or $0.1 \%$ DMSO (control) for 24 to 48 hours. Following this, $20 \mu \mathrm{L}$ of 3-(4,5-dimethylthiazol-2-yl)-5-(3-carboxymethoxyphenyl)-2-(4-sulfophenyl)-2H-tetrazolium inner salt was added to each well and incubated for an additional 3 hours. The relative cell proliferation rates were determined indirectly by quantifying the color developed at $490 \mathrm{~nm}$ using a 96-well plate reader. Each experiment was performed in triplicate, and repeated a minimum of three times with three independent cultures.

\section{Annexin V staining}

Annexin V staining was performed using the Annexin-V-FITC apoptosis detection kit (BD Pharmingen, San Diego, CA, USA) according to the manufacturer's protocols. Briefly, cells were harvested, resuspended in $100 \mu \mathrm{L}$ binding buffer, and stained with $5 \mu \mathrm{L}$ Annexin-V-FITC staining solution in the dark at room temperature (RT) for 15 minutes. The samples were analyzed by flow cytometry (Becton Dickenson, Franklin Lakes, NJ, USA) using CellQuest software.

\section{Preparation of cell extracts}

Cells were grown in 150-mm dishes in medium containing $10 \%$ $\mathrm{FBS}$ at $37^{\circ} \mathrm{C}$. After 24 hours, cells were treated with docetaxel (5 $\mathrm{nM})$ and/or curcumin $(10 \mu \mathrm{M})$ or vehicle for 24 hours. Follow- 
ing this, cells were washed twice with ice-cold phosphate buffered saline (PBS), collected in $1 \mathrm{~mL}$ PBS and centrifuged at $4^{\circ} \mathrm{C}$ for 5 minutes at 1,200 rpm. The cell pellet was then resuspended in $50 \mu \mathrm{L}$ of M-PER mammalian protein extraction reagent (Pierce, Rockford, IL, USA) containing a cocktail of protease inhibitors (Pierce). After incubating for 20 minutes on ice, the lysate was centrifuged for 10 minutes at 14,000 rpm. The supernatant was stored at $-80^{\circ} \mathrm{C}$ until use. Protein concentrations were determined using a BCA protein assay kit (Pierce) according to manufacturer's protocol. Nuclear extracts was prepared from cells using the NE-PER nuclear and cytoplasmic extraction kit (Pierce) following the manufacturer's instructions.

\section{Western blotting}

Forty micrograms of protein was loaded onto $10 \%$ to $15 \%$ polyacrylamide gels and separated by sodium dodecylsulfatepolyacrylamide gel electrophoresis (SDS-PAGE). Separated
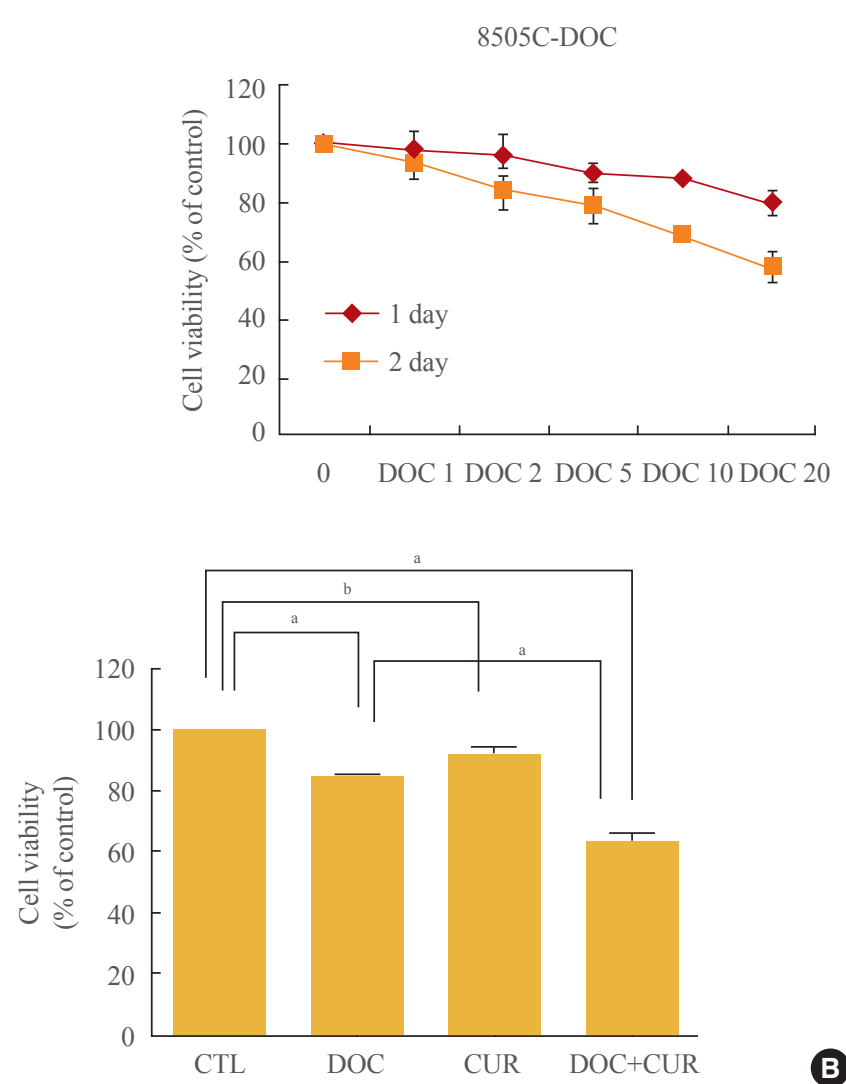

B proteins were transferred onto a nitrocellulose membrane (Millipore Corp., Bedford, MA, USA) and blocked with Tris-buffered saline $/ 0.1 \%$ Tween 20 (TBST) containing 5\% nonfat dry milk for 1 hour at RT. After washing four times with TBST, membranes were incubated with desired concentrations of primary antibodies in blocking solution at $4^{\circ} \mathrm{C}$ overnight. After washing four times with TBST, the blots were incubated with horseradish peroxidase-conjugated species-specific secondary antibodies (Santa Cruz Biotechnology) in TBST for 1 hour at RT. The blots were washed again four times with TBST, and the complexes were visualized using an Immun-Star WesternC Chemiluminescent kit (Bio-Rad, Hercules, CA, USA) in a BioRad Molecular Imager ChemiDoc XRS imaging system (BioRad). Western blotting was performed using lysates from at least three independent experiments. Intensities of the bands developed after the application of HRP substrate were quantified using the Bio-Rad Molecular Imager ChemiDoc XRS imaging system (Bio-Rad). Relative expression levels of various
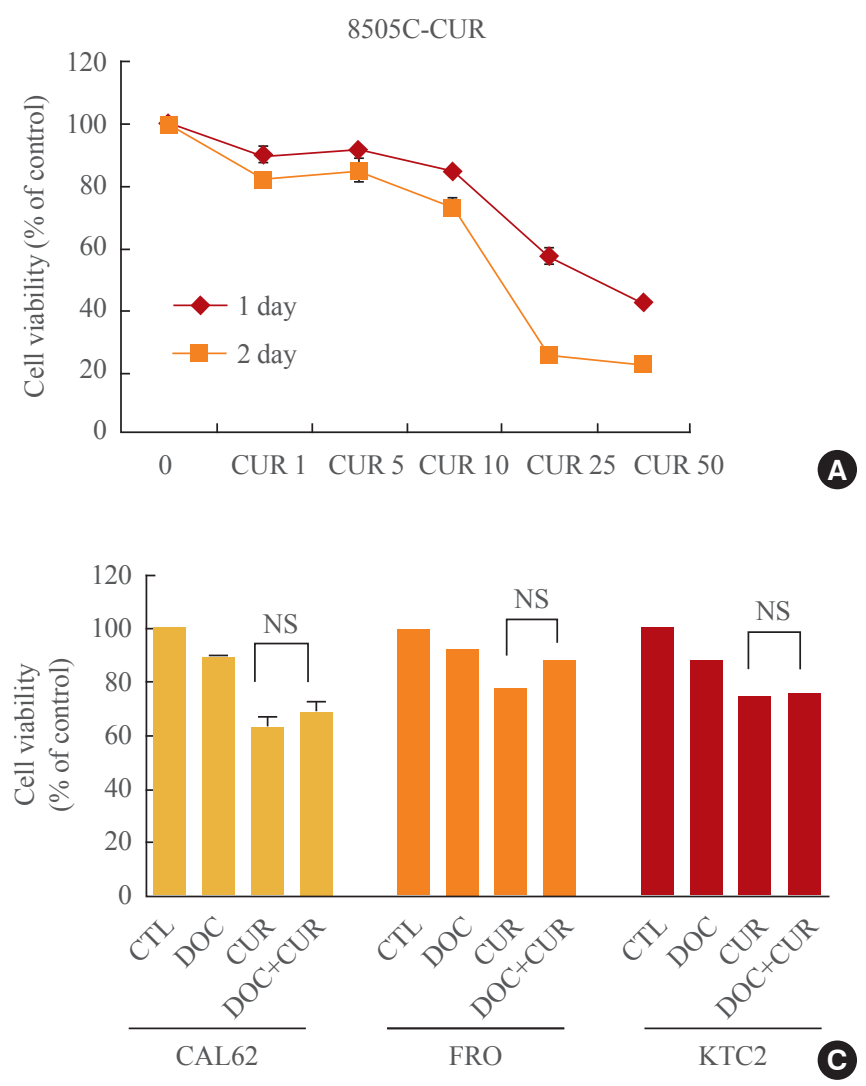

Fig. 1. Effects of docetaxel and/or curcumin treatment on the proliferation of 8505C, CAL62, FRO, and KTC2 cells. (A) 8505C cells were grown on 96-well plates and treated with varying doses of docetaxel (DOC) or curcumin (CUR) for 24 hours. (B) 8505C cells were grown on 96-well plates and treated with a combination of docetaxel $(5 \mathrm{nM})$ and curcumin $(10 \mu \mathrm{M})$ for 24 hours. (C) CAL62, FRO, and KTC2 cells were treated with docetaxel $(5 \mathrm{nM})$ and curcumin $(10 \mu \mathrm{M})$. Bars represent mean \pm SD. CTL, cell only; NS, no significant. ${ }^{\mathrm{a}} P<0.001 ;{ }^{\mathrm{b}} P<0.05$. 
proteins were estimated by densitometric analysis using actin expression levels as a standard.

\section{Statistical analysis}

All data are expressed as the mean $\pm \mathrm{SD}$. Differences between groups were examined for statistical significance by performing analysis of variance (GraphPad Prism program) and/or Student $t$ tests. $P<0.05$ indicated a statistically significant difference.

\section{RESULTS}

\section{Docetaxel in combination with curcumin induces enhanced} cell death in $8505 \mathrm{C}$ anaplastic thyroid carcinoma cells

Both docetaxel $(1,2,5,10$, and $20 \mathrm{nM})$ and curcumin $(1,5$, $10,25$, and $50 \mu \mathrm{M})$ used independently showed inhibitory effects on ATC cell proliferation. Compared to controls, cotreatment with docetaxel and curcumin significantly reduced the number of cells (Fig. 1A, B). Treatment of 8505C cells with 25 $\mu \mathrm{M}$ curcumin resulted in $50 \%$ growth inhibition. Importantly, the addition of treatment with $5 \mathrm{nM}$ docetaxel resulted in a 2.5fold decrease in the curcumin concentration that was needed to achieve $50 \%$ growth-inhibition. Therefore, we conducted experiments using $10 \mu \mathrm{M}$ curcumin and $5 \mathrm{nM}$ docetaxel. Al- though we attempted to extend our findings to other well-established cellular models of human ATCs (CAL62, FRO, and KTC2), we did not observe the synergistic effects of docetaxel and curcumin as observed in $8505 \mathrm{C}$ cells (Fig. 1C).

\section{Docetaxel in combination with curcumin enhances apoptosis in $8505 \mathrm{C}$ thyroid carcinoma cells}

To confirm the effects of cotreatment with docetaxel and curcumin on $8505 \mathrm{C}$ cells, the cells were treated with the drugs for 24 hours. After Annexin V staining, cells were analyzed by flow cytometry. Cells treated with a combination of docetaxel and curcumin showed increased Annexin V staining as compared with cells treated with either docetaxel or curcumin alone (Fig. 2).

\section{Increased expression of proapoptotic proteins in $8505 \mathrm{C}$} cells treated with docetaxel and curcumin

To identify the mechanism underlying the enhanced apoptotic response of $8505 \mathrm{C}$ cells to co-treatment with docetaxel and curcumin, we assessed the expression of proapoptotic proteins by SDS-PAGE followed by Western blotting. Cells were treated with $5 \mathrm{nM}$ docetaxel and $10 \mu \mathrm{M}$ curcumin for 24 hours, and whole-cell lysates were subjected to Western blotting. Cotreatment with curcumin and docetaxel increased the expression of
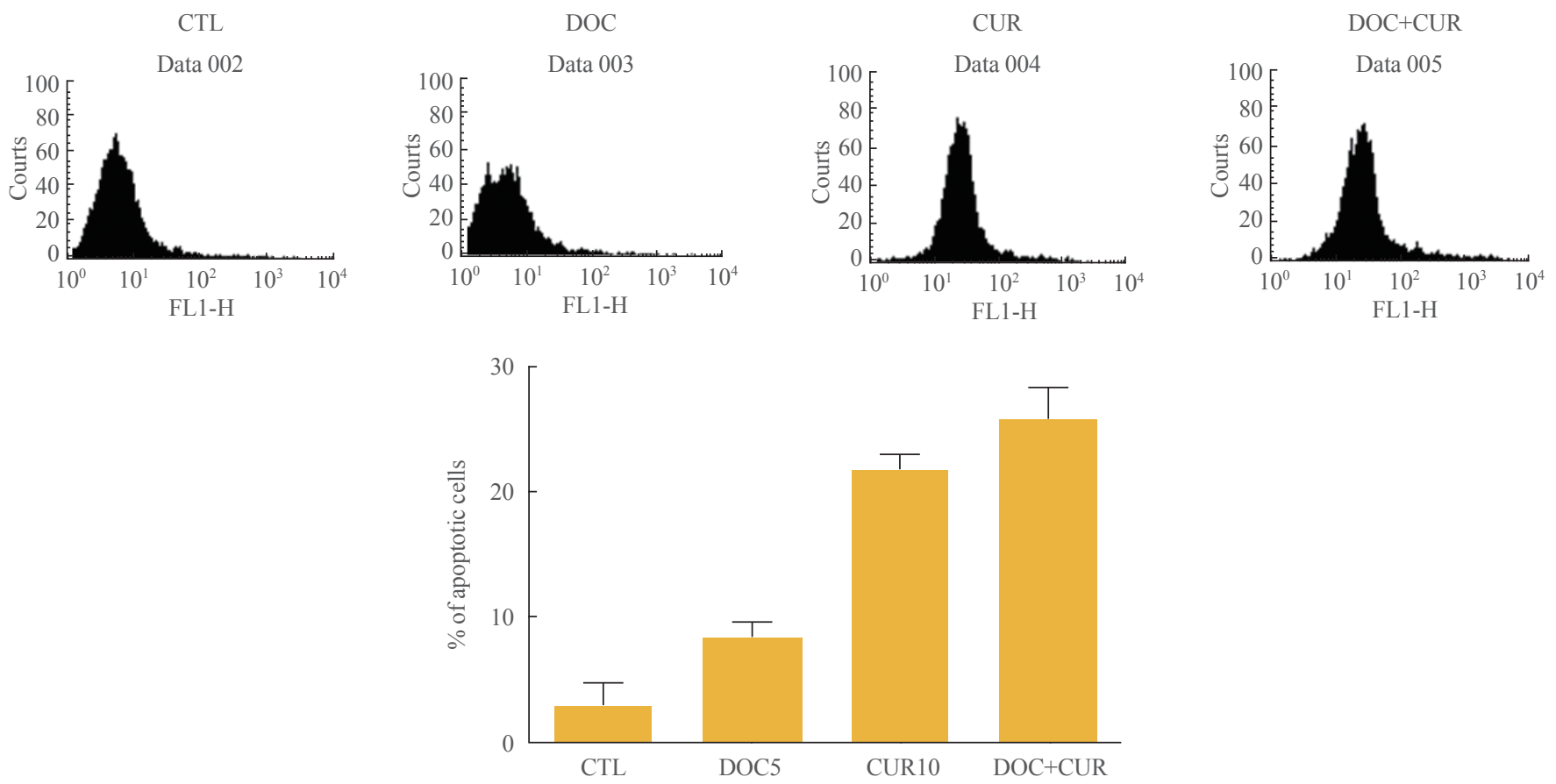

Fig. 2. Apoptosis-promoting effects of docetaxel (DOC) and curcumin (CUR) treatment. 8505C cells were cultured in 100-mm petri dishes and treated with docetaxel $(5 \mathrm{nM})$ and/or curcumin $(10 \mu \mathrm{M})$ for 24 hours. Apoptosis was assessed by Annexin V staining followed by flow cytometry analysis. Bars represent mean \pm SD. CTL, control. 
proapoptotic proteins. Compared to controls, an active form of caspase-3 (cleaved caspase-3, 17-, and 19-kDa bands), and caspase-9 (including cleaved caspase-9, $37 \mathrm{kDa}$ ) were significantly increased in cells treated with docetaxel and curcumin (Fig. 3).

\section{Effects of docetaxel and curcumin on NF- $\mathrm{KB}$ activation and COX-2 expression}

To examine the effects of docetaxel on NF- $\kappa \mathrm{B}$ signaling, cells were treated with docetaxel and/or curcumin for 24 hours, and nuclear extracts from drug-treated cells were subjected to Western blotting. Compared to controls, the presence of p65 in the nuclear fraction was markedly decreased in cells treated with curcumin alone or with curcumin and docetaxel (Fig. 4). These results confirmed not only the phenomenon of docetaxel-induced NF- $\kappa \mathrm{B}$ activation but also that curcumin inhibited this process (Fig. 4). Further, we found that curcumin treatment resulted in the down-regulation of COX-2 protein expression (Fig. 5).
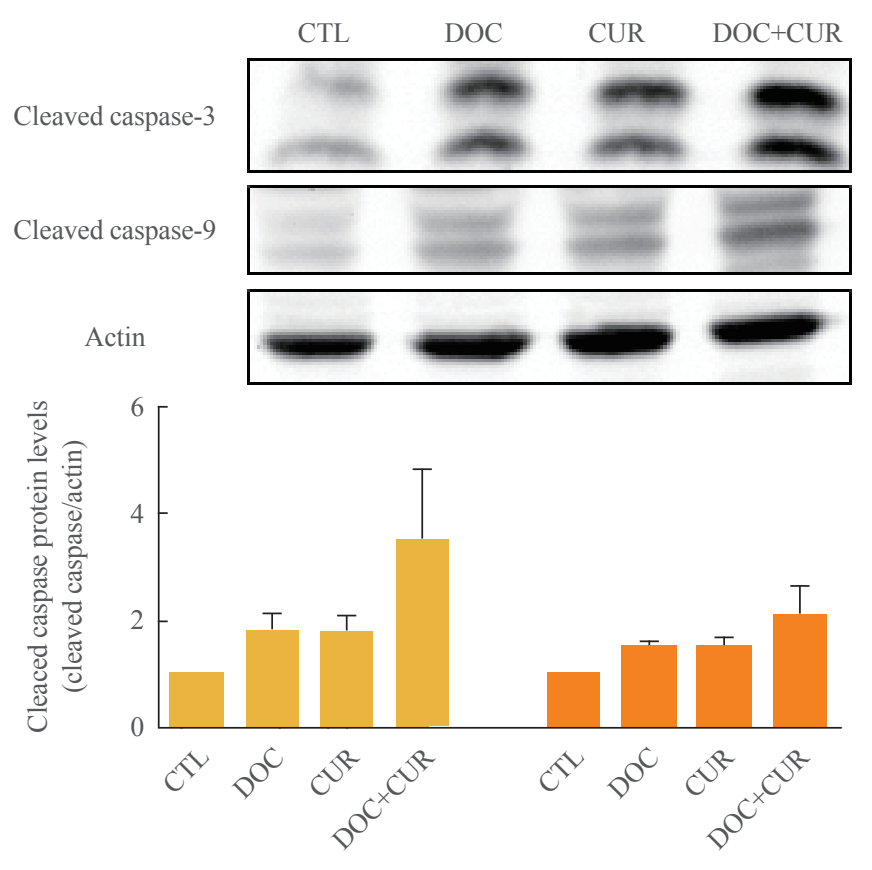

Cleaved caspase-3

Cleaved caspase-9

Fig. 3. Effects of docetaxel (DOC) and curcumin (CUR) treatment on the expression of proapoptotic proteins. $8505 \mathrm{C}$ cells were treated with docetaxel $(5 \mathrm{nM})$ and/or curcumin $(10 \mu \mathrm{M})$ for 24 hours. Expression of cleaved caspase- 3 and cleaved caspase- 9 were detected by Western blot analysis. Actin was used as an internal control. Relative expression values are presented in the bar graph. Bars represent mean \pm SD. CTL, control.
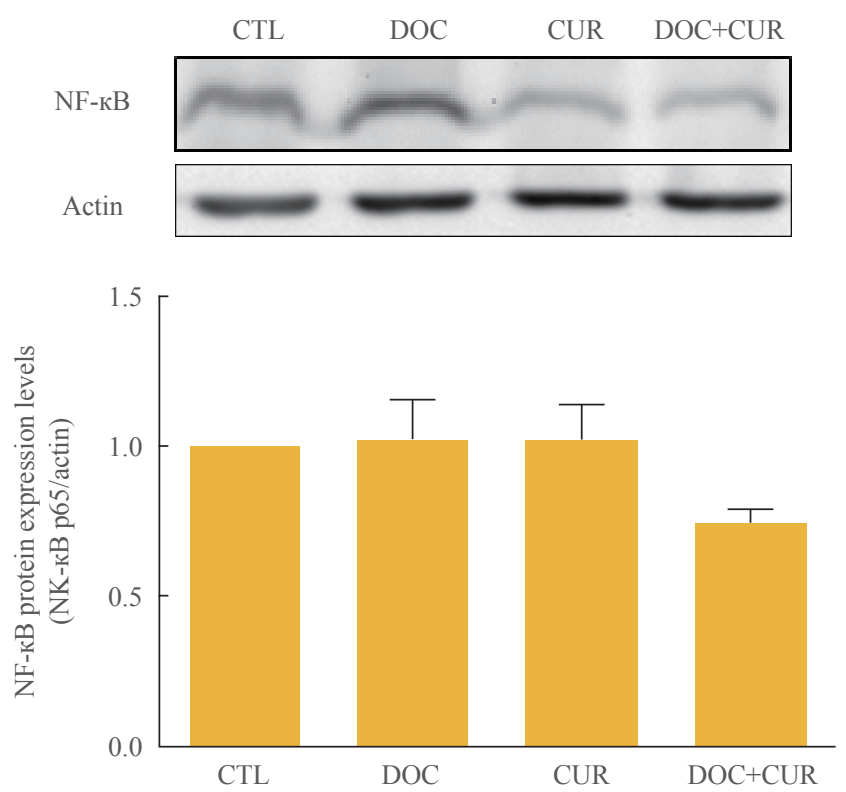

Fig. 4. Effect of docetaxel (DOC) and curcumin (CUR) treatment on the nuclear factor $\kappa \mathrm{B}(\mathrm{NF}-\kappa \mathrm{B})$ pathway. $8505 \mathrm{C}$ cells were treated with docetaxel $(5 \mathrm{nM})$ and/or curcumin $(10 \mu \mathrm{M})$ for 24 hours. Nuclear NF-kB was detected by Western blot analysis. Actin was used as control. Relative expression values are presented in the bar graph. Bars represent mean \pm SD. CTL, control.
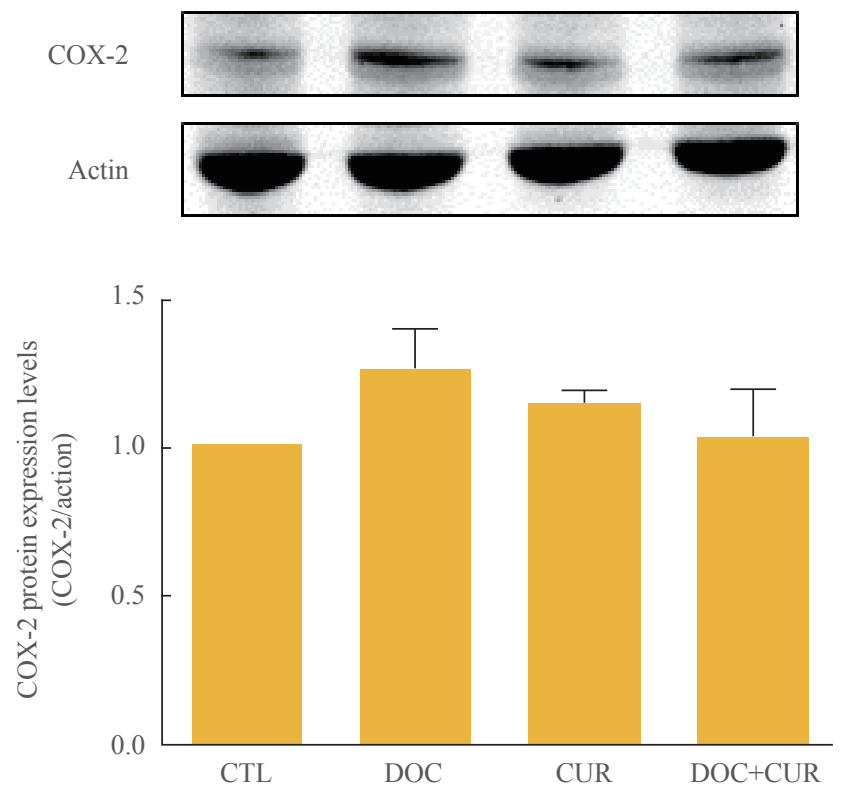

Fig. 5. Effect of docetaxel (DOC) and curcumin (CUR) treatment on the expression of cyclooxygenase-2 $(\mathrm{COX}-2)$ protein. $8505 \mathrm{C}$ cells were treated with docetaxel $(5 \mathrm{nM})$ and/or curcumin $(10$ $\mu \mathrm{M}$ ) for 24 hours. Expression of COX-2 was detected by Western blot analysis. Actin was used as an internal control. Relative expression values are presented in the bar graph. Bars represent mean \pm SD. CTL, control. 


\section{DISCUSSION}

ATC is highly resistant to standard therapeutic interventions, including surgical treatment, radiation therapy, and chemotherapy. Recently, it has been found that targeted therapeutic agents enhance the susceptibility of tumors to ionizing radiation by interfering with intracellular signal transduction pathways and DNA repair, thereby leading to senescence-like terminal growth arrest [19-21].

Previous studies have shown that paclitaxel is a promising candidate for therapeutic intervention in anaplastic thyroid carcinoma cases [21,22]. Docetaxel, similar to paclitaxel, has been shown to be clinically effective against solid tumors. However, chemotherapeutic agents such as taxanes and gemcitabine induce NF- $\mathrm{KB}$ activation, resulting in drug resistance and therapeutic failure.

The transcription factor NF- $\mathrm{BB}$ regulates genes involved in cell survival and proliferation [23]. Thus, NF- $\kappa B$ suppresses apoptosis by up-regulation of antiapoptotic proteins [24]. In addition, elevated basal NF- $\mathrm{KB}$ activity, as found in various types of human cancers, causes resistance to chemotherapy [25-27]. Therefore, the NF- $\kappa B$ signaling pathway has been an attractive target for the development of chemotherapeutic drugs. Combination therapy has the potential of producing synergistic effects on tumor suppression without adverse events. Meng et al. [15] reported that in nude mice xenograft models, a combination of NF-kB inhibitor (DHMEQ) and docetaxel was more effective in inhibiting ATC tumor growth than treatment with either of the drugs alone. However, the NF- $\mathrm{BB}$ inhibitor caused only a transient inhibition of NF- $\mathrm{\kappa B}$ activity, resulting in an early restoration of p65 DNA binding [28].

Curcumin has been reported to inhibit a number of targets, including NF- $\mathrm{KB}, \mathrm{COX}-2$, kinases associated with survival signaling (IKK, NIK, and AKT), ERK, and other proteins involved in cell cycle regulation. Thus, curcumin shows a broad range of activities owing to its ability to target multiple pathways involved in regulating diverse cellular processes [29]. In a previous study, NF- $\mathrm{\kappa B}$ was bound constitutively in melanoma cell lines. NF- $\mathrm{kB}$ binding activity was decreased when treated with curcumin compared with controls [30]. The mechanisms responsible for the inhibition of tumor growth by curcumin are diverse and appear to involve a combination of anti-inflammatory, antioxidant, immunomodulatory, proapoptotic, and antiangiogenic properties via pleiotropic effects on genes and cell signaling pathways at multiple levels [31]. At the molecular level, curcumin disrupts functional and physical interactions between a6ß4 integrins and human epidermal growth factor receptor (EGFR) and blocks integrin a6ß4/EGFR-dependent pathways in carcinoma cells [32], in addition to inhibiting MMP-2, MMP-9, and vascular endothelial growth factor [33].

The potential therapeutic role of curcumin in conjunction with other therapeutic agents has previously been explored [34]. In bladder cancer cell lines, curcumin was shown to act as a counterbalance to reverse paclitaxel-induced NF- $\mathrm{kB}$ activation [35]. Here we demonstrated, for the first time, the synergistic antiproliferative and proapoptotic effects of a combination of docetaxel and curcumin treatment on $8505 \mathrm{C}$ anaplastic thyroid carcinoma cells. In the present study, we found that treatment with docetaxel in combination with curcumin enhanced the inhibition of cell proliferation and increased induction of apoptosis in ATC cells as compared to treatment with docetaxel alone. We also showed that curcumin counteracts the effects of docetaxel on NF- $\mathrm{kB}$ activation and COX-2 expression in $8505 \mathrm{C}$ cells. Thus, docetaxel activated NF- $\mathrm{KB}$ and increased COX-2 expression, and treatment with curcumin suppressed both docetaxel-induced NF- $\mathrm{KB}$ activation and COX-2 expression in 8505C ATC cells.

Induction of COX-2 in tumor cells by docetaxel may be a protective mechanism, counterproductive to the overall antiangiogenic and antitumor effects of docetaxel [36]. COX-2 plays an important role in tumor progression by promoting angiogenesis, stimulating cell growth, and inhibiting apoptotic cell death [37-39]. Cornetta et al. [40] reported that the expression of COX-2 was upregulated in well-differentiated thyroid cancer, and this was not observed in the normal thyroid. Overexpression of COX-2 may inhibit apoptosis, enhance angiogenesis, and promote cell invasion. Our results suggest that curcumin may counteract the adverse clinical outcomes arising from increased expression of COX-2 in ATC cells.

In conclusion, our study results suggest that curcumin augments the therapeutic efficacy of docetaxel by lowering its threshold concentration required for inhibiting cell proliferation and inducing cell death. Additionally, inhibition of docetaxel-induced NF- $\mathrm{kB}$ activation and COX-2 expression by curcumin in $8505 \mathrm{C}$ cells revealed a potential anti-angiogenic effect of the combination therapy. Taken together, our findings will lead to improved clinical outcomes in ATC therapy.

\section{CONFLICTS OF INTEREST}

No potential conflict of interest relevant to this article was reported. 


\section{REFERENCES}

1. Brignardello E, Gallo M, Baldi I, Palestini N, Piovesan A, Grossi E, Ciccone G, Boccuzzi G. Anaplastic thyroid carcinoma: clinical outcome of 30 consecutive patients referred to a single institution in the past 5 years. Eur J Endocrinol 2007; 156:425-30.

2. Karunagaran D, Rashmi R, Kumar TR. Induction of apoptosis by curcumin and its implications for cancer therapy. Curr Cancer Drug Targets 2005;5:117-29.

3. Epstein J, Sanderson IR, Macdonald TT. Curcumin as a therapeutic agent: the evidence from in vitro, animal and human studies. Br J Nutr 2010;103:1545-57.

4. Kawamori T, Lubet R, Steele VE, Kelloff GJ, Kaskey RB, Rao CV, Reddy BS. Chemopreventive effect of curcumin, a naturally occurring anti-inflammatory agent, during the promotion/progression stages of colon cancer. Cancer Res 1999;59:597-601.

5. Aggarwal BB, Shishodia S, Takada Y, Banerjee S, Newman RA, Bueso-Ramos CE, Price JE. Curcumin suppresses the paclitaxel-induced nuclear factor-kappaB pathway in breast cancer cells and inhibits lung metastasis of human breast cancer in nude mice. Clin Cancer Res 2005;11: 7490-8.

6. LoTempio MM, Veena MS, Steele HL, Ramamurthy B, Ramalingam TS, Cohen AN, Chakrabarti R, Srivatsan ES, Wang MB. Curcumin suppresses growth of head and neck squamous cell carcinoma. Clin Cancer Res 2005;11(19 Pt 1):6994-7002.

7. Cruz-Correa M, Shoskes DA, Sanchez P, Zhao R, Hylind LM, Wexner SD, Giardiello FM. Combination treatment with curcumin and quercetin of adenomas in familial adenomatous polyposis. Clin Gastroenterol Hepatol 2006;4: 1035-8.

8. Schiff PB, Fant J, Horwitz SB. Promotion of microtubule assembly in vitro by taxol. Nature 1979;277:665-7.

9. Yvon AM, Wadsworth P, Jordan MA. Taxol suppresses dynamics of individual microtubules in living human tumor cells. Mol Biol Cell 1999;10:947-59.

10. Mason KA, Hunter NR, Milas M, Abbruzzese JL, Milas L. Docetaxel enhances tumor radioresponse in vivo. Clin Cancer Res 1997;3(12 Pt 1):2431-8.

11. Kim JC, Saha D, Cao Q, Choy H. Enhancement of radiation effects by combined docetaxel and flavopiridol treatment in lung cancer cells. Radiother Oncol 2004;71:21321.
12. Reiner T, de las Pozas A, Gomez LA, Perez-Stable C. Low dose combinations of 2-methoxyestradiol and docetaxel block prostate cancer cells in mitosis and increase apoptosis. Cancer Lett 2009;276:21-31.

13. Tannock IF, de Wit R, Berry WR, Horti J, Pluzanska A, Chi KN, Oudard S, Theodore C, James ND, Turesson I, Rosenthal MA, Eisenberger MA; TAX 327 Investigators. Docetaxel plus prednisone or mitoxantrone plus prednisone for advanced prostate cancer. N Engl J Med 2004; 351:1502-12.

14. Kawada K, Kitagawa K, Kamei S, Inada M, Mitsuma A, Sawaki M, Kikumori T, Fujimoto Y, Arima H, Imai T, Ando Y. The feasibility study of docetaxel in patients with anaplastic thyroid cancer. Jpn J Clin Oncol 2010;40:596-9.

15. Meng Z, Mitsutake N, Nakashima M, Starenki D, Matsuse M, Takakura S, Namba H, Saenko V, Umezawa K, Ohtsuru A, Yamashita S. Dehydroxymethylepoxyquinomicin, a novel nuclear factor-kappaB inhibitor, enhances antitumor activity of taxanes in anaplastic thyroid cancer cells. Endocrinology 2008;149:5357-65.

16. Troch M, Koperek O, Scheuba C, Dieckmann K, Hoffmann M, Niederle B, Raderer M. High efficacy of concomitant treatment of undifferentiated (anaplastic) thyroid cancer with radiation and docetaxel. J Clin Endocrinol Metab 2010;95:E54-7.

17. Foote RL, Molina JR, Kasperbauer JL, Lloyd RV, McIver B, Morris JC, Grant CS, Thompson GB, Richards ML, Hay ID, Smallridge RC, Bible KC. Enhanced survival in locoregionally confined anaplastic thyroid carcinoma: a single-institution experience using aggressive multimodal therapy. Thyroid 2011;21:25-30.

18. Kurebayashi J, Otsuki T, Tanaka K, Yamamoto Y, Moriya T, Sonoo H. Medroxyprogesterone acetate decreases secretion of interleukin- 6 and parathyroid hormone-related protein in a new anaplastic thyroid cancer cell line, KTC-2. Thyroid 2003;13:249-58.

19. Kojic SL, Strugnell SS, Wiseman SM. Anaplastic thyroid cancer: a comprehensive review of novel therapy. Expert Rev Anticancer Ther 2011;11:387-402.

20. Harris PJ, Bible KC. Emerging therapeutics for advanced thyroid malignancies: rationale and targeted approaches. Expert Opin Investig Drugs 2011;20:1357-75.

21. Ain KB, Egorin MJ, DeSimone PA. Treatment of anaplastic thyroid carcinoma with paclitaxel: phase 2 trial using ninety-six-hour infusion. Collaborative Anaplastic Thyroid Cancer Health Intervention Trials (CATCHIT) Group. 
Thyroid 2000;10:587-94.

22. Higashiyama T, Ito Y, Hirokawa M, Fukushima M, Uruno T, Miya A, Matsuzuka F, Miyauchi A. Induction chemotherapy with weekly paclitaxel administration for anaplastic thyroid carcinoma. Thyroid 2010;20:7-14.

23. Barkett M, Gilmore TD. Control of apoptosis by Rel/NFkappaB transcription factors. Oncogene 1999;18:6910-24.

24. Lee R, Collins T. Nuclear factor-kappaB and cell survival: IAPs call for support. Circ Res 2001;88:262-4.

25. Zhang H, Morisaki T, Nakahara C, Matsunaga H, Sato N, Nagumo F, Tadano J, Katano M. PSK-mediated NF-kappaB inhibition augments docetaxel-induced apoptosis in human pancreatic cancer cells NOR-P1. Oncogene 2003; 22:2088-96.

26. Nakahara C, Nakamura K, Yamanaka N, Baba E, Wada M, Matsunaga H, Noshiro H, Tanaka M, Morisaki T, Katano M. Cyclosporin-A enhances docetaxel-induced apoptosis through inhibition of nuclear factor-kappaB activation in human gastric carcinoma cells. Clin Cancer Res 2003;9: 5409-16.

27. Domingo-Domenech J, Oliva C, Rovira A, Codony-Servat J, Bosch M, Filella X, Montagut C, Tapia M, Campas C, Dang L, Rolfe M, Ross JS, Gascon P, Albanell J, Mellado B. Interleukin 6, a nuclear factor-kappaB target, predicts resistance to docetaxel in hormone-independent prostate cancer and nuclear factor-kappaB inhibition by PS-1145 enhances docetaxel antitumor activity. Clin Cancer Res 2006; 12:5578-86.

28. Kikuchi E, Horiguchi Y, Nakashima J, Kuroda K, Oya M, Ohigashi T, Takahashi N, Shima Y, Umezawa K, Murai M. Suppression of hormone-refractory prostate cancer by a novel nuclear factor kappaB inhibitor in nude mice. Cancer Res 2003;63:107-10.

29. Shehzad A, Wahid F, Lee YS. Curcumin in cancer chemoprevention: molecular targets, pharmacokinetics, bioavailability, and clinical trials. Arch Pharm (Weinheim) 2010; 343:489-99.

30. Siwak DR, Shishodia S, Aggarwal BB, Kurzrock R. Curcumin-induced antiproliferative and proapoptotic effects in melanoma cells are associated with suppression of Ikap$\mathrm{paB}$ kinase and nuclear factor kappaB activity and are independent of the B-Raf/mitogen-activated/extracellular signal-regulated protein kinase pathway and the Akt pathway. Cancer 2005; 104:879-90.

31. Schaffer M, Schaffer PM, Zidan J, Bar Sela G. Curcuma as a functional food in the control of cancer and inflammation. Curr Opin Clin Nutr Metab Care 2011;14:588-97.

32. Soung YH, Chung J. Curcumin inhibition of the functional interaction between integrin alpha6beta4 and the epidermal growth factor receptor. Mol Cancer Ther 2011;10:88391.

33. Lin SS, Lai KC, Hsu SC, Yang JS, Kuo CL, Lin JP, Ma YS, Wu CC, Chung JG. Curcumin inhibits the migration and invasion of human A549 lung cancer cells through the inhibition of matrix metalloproteinase-2 and -9 and vascular endothelial growth factor (VEGF). Cancer Lett 2009; 285:127-33.

34. Bava SV, Sreekanth CN, Thulasidasan AK, Anto NP, Cheriyan VT, Puliyappadamba VT, Menon SG, Ravichandran SD, Anto RJ. Akt is upstream and MAPKs are downstream of NF-kappaB in paclitaxel-induced survival signaling events, which are down-regulated by curcumin contributing to their synergism. Int J Biochem Cell Biol 2011; 43:331-41.

35. Kamat AM, Sethi G, Aggarwal BB. Curcumin potentiates the apoptotic effects of chemotherapeutic agents and cytokines through down-regulation of nuclear factor-kappaB and nuclear factor-kappaB-regulated gene products in IFNalpha-sensitive and IFN-alpha-resistant human bladder cancer cells. Mol Cancer Ther 2007;6:1022-30.

36. Merchan JR, Jayaram DR, Supko JG, He X, Bubley GJ, Sukhatme VP. Increased endothelial uptake of paclitaxel as a potential mechanism for its antiangiogenic effects: potentiation by Cox-2 inhibition. Int J Cancer 2005;113:490-8.

37. Tsujii M, Kawano S, Tsuji S, Sawaoka H, Hori M, DuBois RN. Cyclooxygenase regulates angiogenesis induced by colon cancer cells. Cell 1998;93:705-16.

38. McGinty A, Chang YW, Sorokin A, Bokemeyer D, Dunn MJ. Cyclooxygenase-2 expression inhibits trophic withdrawal apoptosis in nerve growth factor-differentiated PC12 cells. J Biol Chem 2000;275:12095-101.

39. Ruggeri RM, Sciacchitano S, Vitarelli E, Trimarchi F, Barresi G, Trovato $\mathrm{M}$. Immunoexpression of multidrug-resistance protein 2 and cyclooxygenase 2 in medullary thyroid carcinomas. Arch Pathol Lab Med 2006;130:1014-9.

40. Cornetta AJ, Russell JP, Cunnane M, Keane WM, Rothstein JL. Cyclooxygenase-2 expression in human thyroid carcinoma and Hashimoto's thyroiditis. Laryngoscope 2002;112: 238-42. 